\title{
Mineralocorticoid receptor antagonists in dialysis patients
}

\author{
Mitsuhiro Tawada, Yasuhiro Suzuki, Fumiko Sakata, Masashi Mizuno and Yasuhiko Ito*
}

\begin{abstract}
Mineralocorticoid receptor (MR) antagonists are known to have beneficial effects in patients with cardiovascular disease without renal failure. However, there have been few published studies on the effectiveness of MR antagonists in dialysis patients, and most of the studies were small-sized. The present review focuses on the effectiveness of MR antagonists and the risk of hyperkalemia in dialysis patients. Severe hyperkalemia due to treatment with MR antagonists in dialysis patients is not common, particularly in peritoneal dialysis (PD) patients, and the prospect of cardioprotective effects has been hopeful in both hemodialysis (HD) and PD patients. Further studies are required to establish optimal protocols for the use of MR antagonists in these patients without adverse effects.
\end{abstract}

Keywords: Mineralocorticoid receptor antagonist, Cardiovascular disease, Dialysis patients, Aldosterone, Peritoneal fibrosis

\section{Background}

The number of patients with end-stage renal disease (ESRD) who are undergoing dialysis is increasing. Although dialysis treatment techniques have improved, cardiovascular mortality in dialysis patients is still 10 to 20 times higher than in the general population [1]. In addition, data from the Japanese Society of Dialysis at the end of 2013 showed that heart failure constituted $26.8 \%$ of the main causes of death in dialysis patients in Japan [2]. Mineralocorticoid receptor (MR) antagonists have been reported to improve the prognosis of chronic heart failure $[3,4]$, heart failure after acute myocardial infarction [5], and left ventricular (LV) hypertrophy [6] among patients without renal failure. In contrast in the patients with advanced renal failure, MR antagonists have not been recommended because of concern of causing hyperkalemia $[7,8]$. This review article summarizes the beneficial effects of MR antagonists for patients with cardiovascular disease as discussed in recent reports, and evaluates the efficacy of treatment with MR antagonists and risk of hyperkalemia in patients receiving hemodialysis (HD) and peritoneal dialysis (PD).

\footnotetext{
* Correspondence: yasuito@med.nagoya-u.ac.jp

Department of Nephrology and Renal Replacement Therapy, Nagoya

University Graduate School of Medicine, 65 Tsurumai-cho, Showa-ku, Nagoya 466-8550, Japan
}

(c) The Author(s). 2016 Open Access This article is distributed under the terms of the Creative Commons Attribution 4.0 International License (http://creativecommons.org/licenses/by/4.0/), which permits unrestricted use, distribution, and reproduction in any medium, provided you give appropriate credit to the original author(s) and the source, provide a link to the Creative Commons license, and indicate if changes were made. The Creative Commons Public Domain Dedication waiver (http://creativecommons.org/publicdomain/zero/1.0/) applies to the data made available in this article, unless otherwise stated.
Since 1960 spironolactone has been used as a potassium-sparing diuretic to control edema, hypertension, ascites of cirrhosis, and primary aldosteronism by inhibiting the mineralocorticoid (aldosterone) receptor [9]. Aldosterone acts on epithelial cells such as renal collecting duct tubules and intestinal mucosa, and controls the extracellular fluid volume by increasing sodium reabsorption [10-12]. Because aldosterone is located in the most downstream area of the renin-angiotensinaldosterone system, it has been thought to indirectly cause cardiovascular disorders through the increase of extracellular fluid volume and hypertension [13]. In large cohort studies, MR antagonists showed reduction of mortality in the patients with severe heart failure and acute myocardial infarction complicated by left ventricular dysfunction. These effects were suggested not to be related to hemodynamic effects. $[3,5]$. Patients with primary aldosteronism are known to have a higher incidence of LV hypertrophy, stroke, and microalbuminuria than patients with essential hypertension. In addition, the occurrence rate of LV hypertrophy is higher in patients with primary aldosteronism than in patients with other types of secondary hypertension [14]. These reports suggest that aldosterone can cause direct organ damage independent of blood pressure. 
The MR has been shown to be expressed in many organs such as the brain, heart, and blood vessels; and the MR produces a variety of actions in each organ (Table 1 ) [15-17]. The effects of aldosterone on the cardiovascular system have been widely reported in relation to vascular remodeling $[18,19]$, endothelial dysfunction $[20,21]$, increased oxidative stress [22], vascular inflammation promotion [23], and cardiomyocyte hypertrophy [24], either by aldosterone alone or through cooperative action with angiotensin II or salt intake $[25,26]$.

In the heart, aldosterone has been reported to play a role in inducing cardiac hypertrophy. In particular, aldosterone with salt-loading induces cardiac hypertrophy associated with fibrosis, which is attenuated by MR blockade [24, 27]. Aldosterone and high salt administration for 4 weeks was observed to induce upregulation for nuclear factor (NF) $-\kappa B$, nicotinamide adenine dinucleotide phosphate oxidase (NADPH oxidase), and oxidative stress, leading to increases in monocyte chemoattractant protein-1 (MCP-1), intracellular adhesion molecule 1 (ICAM1), tumor necrosis factor alpha (TNF- $\alpha$ ), and macrophage infiltration in the perivascular area of the intramyocardial coronary arteries and at sites of myocardial injury [22].

The MR, which is expressed not only in the endothelial cells but also in the vascular smooth muscle cells [28], has been reported to be involved in vascular injury. For vascular endothelial cells, aldosterone and the MR are related to endothelial dysfunction, coagulation, inflammation and fibrosis, nitric oxide (NO) synthesis, and

Table 1 Effects of aldosterone in associated disorders [25]

\begin{tabular}{ll}
\hline Effects of aldosterone & Myocardial fibrosis and remodeling \\
& Vascular injury and fibrosis \\
& Reduced vascular compliance \\
& Impaired baroreceptor function \\
& Endothelial dysfunction \\
& Catecholamine potentiation \\
& Ventricular arrhythmias \\
& Progressive renal disease \\
& $\mathrm{K}^{+}$and Mg ${ }^{2+}$ loss \\
& Sodium reabsorption and water \\
& retention \\
& Prothrombotic effects (Increasing PAl-1) \\
Hypertension & Heart failure and cardiac hypertrophy \\
Stroke \\
Ildosterone-associated \\
disorders \\
End-stage renal disease \\
Peritoneal fibrosis
\end{tabular}

PAI-1 plasminogen activator inhibitor-1 oxidative stress [29]. Endothelial dysfunction is one of the factors of atherosclerosis. Aldosterone exacerbates neointimal thickening after balloon injury and is blocked by spironolactone [30]. Aldosterone has been reported to induce a prothrombotic condition by upregulation of plasminogen activator inhibitor-1 [31]. Aldosterone was also shown to induce inflammation through upregulation of oxidative stress, which was ameliorated by spironolactone [32]. Aldosterone was found to downregulate NO production in vascular endothelial cells, resulting in inhibition of vascular relaxation, which was attenuated with MR blockade [33, 34]. Interestingly, in vivo studies in rabbits with high cholesterol diets showed that eplerenone reduced superoxide generation and improved endothelial function [35]. Also, in monkeys receiving high cholesterol diets, eplerenone improved endothelium-dependent relaxation [36]. In the recent report, MR in endothelial cells was shown to play a role in regulating endothelial function in hypertension using the mice with MR specifically deleted in the endothelial cells [37].

In vascular smooth muscle cells, aldosterone induced proliferation [38] and oxidative stress [39]. Aldosterone activated the mitogen-activated protein (MAP) kinases and NADPH oxidase through c-Src, leading to damage of vascular smooth muscle cells [39]. In addition, spironolactone inhibited the progression of aortic calcification in rats with adenine-induced chronic kidney disease (CKD) because of suppression of osteogenic transition and apoptosis in the aorta [40]. Recently, arterial stiffness was shown to be modulated by MR activation in vascular smooth muscle cells using a mouse with conditional inactivation of MR in these cells [41]. The main functions of aldosterone are summarized in Table 1.

\section{Effects of the MR antagonists in hemodialysis patients}

There have been many reports about the cardioprotective effects of MR antagonists and the concomitant risk of hyperkalemia in HD patients (Table 2).

\section{Risk of hyperkalemia}

In a 1983 study, spironolactone at $300 \mathrm{mg} /$ day was administered to $9 \mathrm{HD}$ patients for 3 weeks. At the end of the study, plasma potassium levels were significantly increased [42]. However, the patients in this study had received a higher dose of spironolactone than that used commonly. Saudan et al. [43] reported 14 HD patients who received low-dose spironolactone at $12.5 \mathrm{mg} \times 3$ / week after dialysis sessions for 2 weeks. Then, the dose was increased to $25 \mathrm{mg} \times 3 /$ week and continued for 2 weeks in comparison with $21 \mathrm{HD}$ control patients. The serum potassium levels did not significantly differ between the two groups $(4.9 \pm 0.7$ in the spironolactone group and $4.9 \pm 0.3 \mathrm{mEq} / \mathrm{l}$ in the control group). Hussain et al. [44] reported that $15 \mathrm{HD}$ patients with serum 
Table 2 Effects of MR antagonists in hemodialysis patients

\begin{tabular}{|c|c|c|c|c|c|}
\hline Author & Number of patients & Administration period & Study duration & Results & Change of plasma potassium \\
\hline Papadimitriou et al. [42] & 9 HD patients & Spironolactone 300 mg/day & 3 weeks & Blood pressure remained unchanged. & Plasma potassium levels increased. \\
\hline Saudan et al. [43] & $14 \mathrm{HD}$ patients & $\begin{array}{l}\text { Spironolactone } 12.5 \mathrm{mg} \times \\
3 / \text { week for } 2 \text { weeks; then } \\
\text { increased } 25 \mathrm{mg} \times 3 / \text { week } \\
\text { for } 2 \text { weeks }\end{array}$ & 4 weeks & & $\begin{array}{l}\text { Serum potassium levels did not } \\
\text { differ between spironolactone } \\
\text { group and control group }(4.9 \pm 0.7 \\
\text { vs. } 4.9 \pm 0.3 \mathrm{mEq} / \mathrm{l}, \mathrm{N} . \mathrm{S} .)\end{array}$ \\
\hline Hussain et al. [44] & $15 \mathrm{HD}$ patients & Spironolactone 25 mg/day & 28 days & & $\begin{array}{l}4.6 \pm 0.6 \text { at baseline } 4.9 \pm 0.9 \mathrm{mEq} / \mathrm{l} \\
\text { at study completion }(P=0.14) \text {. } \\
\text { One patient developed hyperkalemia } \\
(\mathrm{K}=7.6 \mathrm{mEq} / \mathrm{l}) \text {. }\end{array}$ \\
\hline Nitta et al. [55] & 5 HD patients & Spironolactone 50 mg/day & $3.1 \pm 1.2$ years & $\begin{array}{l}\text { ACl decreased. } \\
\text { Plasma osteopontin decreased. }\end{array}$ & \\
\hline Gross et al. [45] & $8 \mathrm{HD}$ patients & Spironolactone $50 \mathrm{mg} \times 2 /$ day & 2 weeks & $\begin{array}{l}\text { Systolic blood pressure reduced. } \\
\text { Plasma aldosterone and renin activity } \\
\text { were not significantly different from } \\
\text { placebo group. }\end{array}$ & $\begin{array}{l}\text { Spironolactone group } 5.0 \pm 0.8 \text { versus } \\
\text { placebo group } 4.7 \pm 0.5 \mathrm{mEq} / /(P>0.05) \text {. }\end{array}$ \\
\hline Taheri et al. [48] & $\begin{array}{l}8 \mathrm{HD} \text { patients with } \\
\text { heart failure and } \\
\text { LVEF } \leq 45 \%\end{array}$ & Spironolactone $25 \mathrm{mg} \times 3 /$ week & 6 months & LVEF and LV mass improved. & $\begin{array}{l}\text { Potassium level increased by } 21 \% \text { in } \\
\text { the spironolactone group. }\end{array}$ \\
\hline McGill et al. [49] & $13 \mathrm{HD}$ patients & Spironolactone 25 mg/day & 9 months & Cardiac MRI was not improved.. & $\begin{array}{l}\text { There was no incidence of hyperkalemia } \\
(K>6.0 \mathrm{mEq} / \mathrm{l}) \text {. }\end{array}$ \\
\hline Matsumoto et al. [53] & $61 \mathrm{HD}$ patients & Spironolactone 25 mg/day & 6 months & & $\begin{array}{l}\text { Potassium levels were } 4.96 \pm 0.72 \text { at } \\
\text { baseline and } 5.18 \pm 0.72 \mathrm{mEq} / \mathrm{l} \text { at } 6 \\
\text { months }(P<0.05) \text {. No patients } \\
\text { developed over } 6.8 \mathrm{mEq} / \mathrm{l} \text {. }\end{array}$ \\
\hline Vukusich et al. [56] & 33 HD patients & Spironolactone $50 \mathrm{mg} \times 3 /$ week & 2 years & CIMT decreased. & $\begin{array}{l}\text { No patients developed hyperkalemia, } \\
\text { but the potassium levels in the } \\
\text { spironolactone group increased } \\
(P<0.001) \text {. }\end{array}$ \\
\hline Shavit et al. [46] & $8 \mathrm{HD}$ patients & Eplerenone 25 mg × 2/day & 4 weeks & Systolic blood pressure reduced. & $\begin{array}{l}\text { Plasma potassium concentration was } \\
4.67 \pm 0.2 \text { at baseline and } 4.86 \pm 0.38 \\
\mathrm{mEq} / \mathrm{l} \text { after } 4 \text { weeks }(P=0.48)\end{array}$ \\
\hline Flevari et al. [50] & $14 \mathrm{HD}$ patients & Spironolactone $25 \mathrm{mg} \times 3 /$ week & 4 months & $\begin{array}{l}\text { Blood pressure controlled, the reactive } \\
\text { hyperemia and heart rate variability } \\
\text { improved. LV dimensions and mass } \\
\text { were not improved. }\end{array}$ & $\begin{array}{l}\text { The potassium level increased from } \\
4.4 \pm 0.2 \text { to } 5.5 \pm 0.3 \mathrm{mEq} / \mathrm{l}(P<0.05) \text {. } \\
\text { Two patients took cation exchange } \\
\text { resin due to hyperkalemia }(K>6 \mathrm{mEq} / \mathrm{l}) \text {. }\end{array}$ \\
\hline Matsumoto et al. [52] & $157 \mathrm{HD}$ patients & Spironolactone 25 mg/day & 3 years & $\begin{array}{l}\text { Death or hospitalization for CCV } \\
\text { events and all-cause mortality reduced. }\end{array}$ & $\begin{array}{l}\text { Potassium level was } 5.16 \text { at baseline vs. } \\
5.14 \mathrm{mEq} / \mathrm{l} \text { after } 3 \text { years. Three patients } \\
\text { discontinued in spironolactone because } \\
\text { of hyperkalemia. }\end{array}$ \\
\hline Walsh et al. [47] & 77 HD patients & Eplerenone 50 mg/day & 13 weeks & $\begin{array}{l}\text { Discontinuation of the drug because } \\
\text { of hyperkalemia or hypotension was } \\
\text { not different. }\end{array}$ & $\begin{array}{l}\text { Nine patients developed hyperkalemia } \\
(K>6.5 \mathrm{mEq} / \mathrm{l}) \text { in the eplerenone group } \\
\text { compared with two patients in the } \\
\text { placebo group. }\end{array}$ \\
\hline
\end{tabular}


Table 2 Effects of MR antagonists in hemodialysis patients (Continued)

\begin{tabular}{|c|c|c|c|c|c|}
\hline Feniman-De-Stefano et al. [51] & $8 \mathrm{HD}$ patients & Spironolactone 25 mg/day & 6 months & LV mass index decreased. & $\begin{array}{l}\text { There was no significant difference } \\
\text { between spironolactone and placebo } \\
\text { groups }(5.0 \pm 0.31 \text { in the spironolactone } \\
\text { group vs } 4.9 \pm 0.24 \mathrm{mEq} / \mathrm{l} \text { in the control } \\
\text { group, } P=0.568) \text {. }\end{array}$ \\
\hline Lin et al. [54] & $125 \mathrm{HD}+$ PD patients & Spironolactone 25 mg/day & 2 years & $\begin{array}{l}\text { CCV events and the rates of death } \\
\text { from all causes reduced. LV mass } \\
\text { index, LVEF, and FMD were improved. }\end{array}$ & $\begin{array}{l}\text { Potassium level rose from } 4.12 \pm 0.42 \text { to } \\
5.32 \pm 0.68 \mathrm{mEq} / \mathrm{l} \text { after } 2 \text { years, but was } \\
\text { not significantly elevated compared with } \\
\text { the control group }(P=0.13) \text {. }\end{array}$ \\
\hline
\end{tabular}

$\overline{A C l}$ aortic calcification index, $C C V$ cardiovascular and cerebrovascular, $C I M T$ carotid intima-media thickness, EF ejection fraction, ESRD end-stage renal disease, $F M D$ flow-mediated dilation, $H D$ hemodialysis, $L V$ left ventricular, MR mineralocorticoid receptor, MRI magnetic resonance imaging, $P D$ peritoneal dialysis, N.S. not significant 
potassium levels $<5.6 \mathrm{mEq} / \mathrm{l}$ were treated with spironolactone at $25 \mathrm{mg} /$ day for 28 days. The mean potassium levels did not significantly increase (before - $4.6 \pm$ $0.6 \mathrm{mEq} / \mathrm{l}$; after $-4.9 \pm 0.9 \mathrm{mEq} / \mathrm{l}, P=0.14$ ); however, the potassium level of one patient rose to $7.6 \mathrm{mEq} / \mathrm{l}$, and this patient was dropped from the study. Gross et al. [45] reported a randomized, double-blinded, placebocontrolled study in which $8 \mathrm{HD}$ patients were administered spironolactone $50 \mathrm{mg} \times 2 /$ day or placebo for 2 weeks; after a 3-week washout period, the patients crossed over in the treatment arms for 2 more weeks. After administration of spironolactone for 2 weeks, systolic blood pressure was significantly reduced from $142.0 \pm 19.6$ to $131.4 \pm 18.2 \mathrm{mmHg} \quad(P<0.05)$. In contrast, plasma potassium levels were not different between spironolactone treatment and placebo groups $(5.0 \pm 0.8$ vs $4.7 \pm 0.5 \mathrm{mEq} / \mathrm{l}, P=$ n.s.). Similar trials were reported using eplerenone, another MR antagonist. Shavit et al. [46] treated $8 \mathrm{HD}$ patients with low-dose eplerenone at $25 \mathrm{mg} \times 2 /$ day for 4 weeks. After 4 weeks, the systolic blood pressure was reduced from $166 \pm 14$ to $153 \pm 10 \mathrm{mmHg}(P<0.05)$; however, there was no significant change in the potassium level (before - 4.67 \pm $0.2 \mathrm{mEq} / \mathrm{l}$, after $-4.86 \pm 0.38 \mathrm{mEq} / \mathrm{l}, \quad P=0.48)$. In addition, Walsh et al. [47] conducted a randomized, double-blinded, placebo-controlled study of $154 \mathrm{HD}$ patients. In the study, 77 and 77 patients were treated with eplerenone $50 \mathrm{mg} /$ day or placebo, respectively, and followed for 13 weeks. Nine patients developed hyperkalemia $(\mathrm{K}>6.5 \mathrm{mEq} / \mathrm{l})$ in the eplerenone group compared with two patients in the placebo group (relative risk, 4.5; 95\% confidence interval, CI 1.0-20.2); however, there was no significant difference in the dropout rate from adverse events (hyperkalemia or hypotension) between the two groups.

\section{Effects on cardiovascular disease}

The effects of MR blockade on cardiac function in HD patients have also been reported. First, Taheri et al. [48] conducted a randomized, double-blinded, placebocontrolled study in $16 \mathrm{HD}$ patients with heart failure and low LV ejection fraction (EF) $\leq 45 \%$, who received spironolactone at $25 \mathrm{mg} \times 3 /$ week $(n=8)$ or placebo $(n$ $=8$ ). After 6 months, the mean EF significantly increased in the spironolactone group compared with the placebo group $(6.2 \pm 1.64$ vs. $0.83 \pm 4.9 \%, P=0.046)$, and the mean LV mass decreased in the spironolactone group compared with the placebo group $(-8.4 \pm 4.72$ vs. $3 \pm$ $7.97 \%, P=0.021)$. The potassium level increased by $21 \%$ in the spironolactone group, but the incidence of hyperkalemia was not significantly increased. McGill et al. [49] conducted a small-sized study of $13 \mathrm{HD}$ patients treated with spironolactone at $25 \mathrm{mg} /$ day for 9 months and evaluated LV mass by cardiac magnetic resonance imaging. No improvements in LV mass were detected. Another research group reported a small-sized study with $14 \mathrm{HD}$ patients without heart failure who received low-dose spironolactone at $25 \mathrm{mg} \times 3 /$ week. After 4 months, blood pressure control, reactive hyperemia, and heart rate variability were significantly improved, while LV dimensions or mass were not improved [50]. Feniman-De-Stefano et al. [51] conducted a small-sized randomized, double-blinded, placebo-controlled study in which $17 \mathrm{HD}$ patients were divided into 2 groups. Eight HD patients received spironolactone and 9 patients received placebo for 6 months; the spironolactone was administered at $12.5 \mathrm{mg} /$ day for 1 week, after which the dose was increased to $25 \mathrm{mg} /$ day. The LV mass index was significantly reduced from $77 \pm 14.6 \mathrm{~g} / \mathrm{m}^{2.7}$ to $69 \pm$ $10.5 \mathrm{~g} / \mathrm{m}^{2.7}(P=0.039)$ in the spironolactone group, whereas in the placebo group there was an increase from $71 \pm 14.2$ to $74 \pm 17.4 \mathrm{~g} / \mathrm{m}^{2.7}(P>0.05)$.

Matsumoto et al. [52] conducted a large-scale randomized trial in HD patients. These investigators performed a pilot study to evaluate the safety of spironolactone. Sixty-one HD patients received spironolactone at $25 \mathrm{mg} /$ day for 6 months. The mean potassium level was significantly higher at the end of the study than at baseline, but no patients developed a potassium level $>6.8 \mathrm{mEq} / \mathrm{l}$ [53]. Based on the safety of this pilot study, Matsumoto et al. [52] conducted a 3-year follow-up randomized trial. One hundred fifty-seven HD patients who received spironolactone at $25 \mathrm{mg} /$ day were compared with 152 control patients. The composite rate of death or hospitalization due to cardiovascular and cerebrovascular (CCV) events during 3 years was $5.7 \%$ in the spironolactone group and $12.5 \%$ in the control group. Death from all causes was $6.4 \%$ in the spironolactone group and $19.7 \%$ in the control group. The average potassium level did not increase significantly; however, 3 patients in the spironolactone group discontinued the study because of developing hyperkalemia during the study. Lin et al. [54] also reported a multicenter, randomized, placebocontrolled study in which $125 \mathrm{HD}+\mathrm{PD}$ patients received spironolactone at $25 \mathrm{mg} /$ day and 128 patients received placebo for 2 years. Death from CCV events occurred in $4.0 \%$ of the spironolactone group vs $11.7 \%$ in the control group. All-cause mortality was $9.6 \%$ in the spironolactone group and $19.5 \%$ in the control group. LV mass index, LVEF, and flow-mediated dilation were significantly improved from baseline in the spironolactone group but not in the control group. The potassium level rose from 4.12 \pm 0.42 to $5.32 \pm 0.68 \mathrm{mEq} / \mathrm{l}$ but was not significantly elevated compared with the control group. Three patients in the spironolactone group experienced an increase in their plasma potassium levels up to $6.0 \sim 6.5 \mathrm{mEq} / \mathrm{l}$.

The effects of spironolactone on blood vessels have also been reported. Nitta et al. [55] reported a small 
study in which $5 \mathrm{HD}$ patients received spironolactone for $3.1 \pm 1.2$ years and were evaluated for the aortic calcification index (ACI) by abdominal computed tomography scan. The mean ACI was significantly decreased from $27.0 \pm 12.8$ to $18.6 \pm 11.8 \%(P=0.003)$. Vukusich et al. [56] performed a randomized, double-blinded, placebo-controlled trial in $33 \mathrm{HD}$ patients who received spironolactone at $50 \mathrm{mg} \times 3 /$ week and in $33 \mathrm{HD}$ control patients. After 2 years, carotid intima-media thickness significantly improved in the spironolactone group compared with the placebo group.

Taken together, hyperkalemia does not commonly occur in HD patients who receive treatment with MR antagonists; however, attention should be paid to serum potassium levels. Cardioprotective effects have been shown in many reports. Two reports described an improvement in mortality [52, 54]; therefore, MR antagonists hold promise for improving the prognosis in HD patients.

\section{Effects of MR antagonists in peritoneal dialysis patients Cardioprotective effects and risk of hyperkalemia in peritoneal dialysis patients}

The number of reports on MR antagonists with respect to their cardioprotective effects and adverse effects in PD patients, summarized in Table 3, has been fewer than the number of reports in HD patients. In 2002, Hausmann et al. [57] first reported a 73-year-old patient on PD who received spironolactone at $25 \mathrm{mg} /$ day, in whom the $\mathrm{EF}$ improved from 32 to $46 \%$ after 10 months. Taheri et al. [58] conducted a small-sized randomized, double-blinded, placebo-controlled study in which 18 PD patients with heart failure received spironolactone at $25 \mathrm{mg}(n=9)$ or placebo $(n=9)$ every other day for 6 months. The EF in the placebo group did not change (before $-33.3 \pm 11.7$ vs after - $34.2 \pm 11.6, P=0.363)$; however, the EF in the spironolactone group significantly improved (before $-25.7 \pm$ 7.3 vs after $-33.3 \pm 7.8, P=0.002$ ). Although there was no significant difference in the serum potassium level between the spironolactone and placebo groups, one patient in the spironolactone group developed hyperkalemia with $\mathrm{K}=5.70 \mathrm{mEq} / \mathrm{l}$. After the Taheri study, Yongsiri et al. [59] reported a small-sized, randomized, double-blinded, placebo-controlled, crossover study that focused on changes in potassium levels. Twenty-four PD patients with hypokalemia received spironolactone at $25 \mathrm{mg} /$ day for 4 weeks. The serum potassium levels did not change significantly $(4.23 \pm 0.64$ vs $3.90 \pm 0.59 \mathrm{mEq} / \mathrm{l}$ in the patients who received spironolactone, $P=0.077$ ), but one patient in the spironolactone group developed hyperkalemia with $\mathrm{K}=5.6 \mathrm{mEq} / \mathrm{l}$.

Because most of the studies on the effects of spironolactone in dialysis patients have been small-sized, we conducted a multicenter, open-label, prospective, randomized trial to investigate the add-on effects of MR antagonists in PD patients [60]. One hundred fifty-eight PD patients treated with an angiotensin-converting

Table 3 Effects of MR antagonists in peritoneal dialysis patients

\begin{tabular}{|c|c|c|c|c|c|}
\hline Author & Number of patients & $\begin{array}{l}\text { Administration } \\
\text { period }\end{array}$ & $\begin{array}{l}\text { Study } \\
\text { duration }\end{array}$ & Results & Change of plasma potassium \\
\hline $\begin{array}{l}\text { Hausmann et al. } \\
\text { [57] }\end{array}$ & One PD patient & $\begin{array}{l}\text { Spironolactone } \\
25 \mathrm{mg} / \text { day }\end{array}$ & 10 months & LVEF increased. & $\begin{array}{l}\text { Potassium level was below } 5.1 \text { at pretreatment } \\
\text { and below } 5.5 \mathrm{mEq} / \mathrm{l} \text { after spironolactone } \\
\text { treatment. }\end{array}$ \\
\hline Taheri et al. [58] & $\begin{array}{l}9 \text { PD patients with } \\
\text { heart failure }\end{array}$ & $\begin{array}{l}\text { Spironolactone } \\
25 \text { mg every } \\
\text { other day }\end{array}$ & 6 months & LVEF increased. & $\begin{array}{l}\text { There was no significantly difference between } \\
\text { spironolactone and placebo groups }(P>0.05) \text {. } \\
\text { One patient in the spironolactone group } \\
\text { developed hyperkalemia }(K=5.70 \mathrm{mEq} / \mathrm{l}) \text {. }\end{array}$ \\
\hline Ito et al. [60] & 78 PD patients & $\begin{array}{l}\text { Spironolactone } \\
25 \mathrm{mg} / \text { day }\end{array}$ & 2 years & $\begin{array}{l}\text { LV mass index and } \\
\text { LVEF improved. }\end{array}$ & $\begin{array}{l}\text { Potassium levels were significantly higher in the } \\
\text { spironolactone group after } 6 \text { and } 12 \text { months } \\
(P<0.05) \text {. } \\
\text { Two patients in the spironolactone group } \\
\text { developed hyperkalemia }(\mathrm{K}=6.0 \mathrm{mEq} / \mathrm{l}) \text {, and } \\
\text { one patient }(\mathrm{K}=6.1 \mathrm{mEq} / \mathrm{l}) \text { in the control group. }\end{array}$ \\
\hline Yongsiri et al. [59] & $\begin{array}{l}24 \text { PD patients } \\
\text { with hypokalemia }\end{array}$ & $\begin{array}{l}\text { Spironolactone } \\
25 \mathrm{mg} / \text { day }\end{array}$ & 4 weeks & & $\begin{array}{l}\text { Potassium levels } 4.23 \pm 0.64 \text { at base line and } \\
3.90 \pm 0.59 \mathrm{mEq} / \mathrm{l} \text { after } 4 \text { weeks }(P=0.077) \text {. One } \\
\text { patient in the spironolactone group developed } \\
\text { hyperkalemia }(K=5.6 \mathrm{mEq} / \mathrm{l}) \text {. }\end{array}$ \\
\hline Yelken et al. [72] & 23 PD patients & $\begin{array}{l}\text { Spironolactone } \\
25 \mathrm{mg} / \text { day }\end{array}$ & 6 months & $\begin{array}{l}\text { Dialysate CA125 } \\
\text { increased. } \\
\text { Residual GFR } \\
\text { declined. }\end{array}$ & $\begin{array}{l}\text { Potassium level } 4.3 \pm 0.5 \text { at baseline and } 4.4 \pm \\
0.6 \mathrm{mEq} / \mathrm{l} \text { after } 6 \text { months }(P=0.488)\end{array}$ \\
\hline $\begin{array}{l}\text { Vazquez-Rangel } \\
\text { et al. [73] }\end{array}$ & 9 PD patients & $\begin{array}{l}\text { Spironolactone } \\
25 \mathrm{mg} / \text { day }\end{array}$ & 6 months & $\begin{array}{l}\text { CD20 and collagen } \\
\text { IV levels in peritoneal } \\
\text { biopsy specimens } \\
\text { decreased. }\end{array}$ & $\begin{array}{l}\text { Potassium levels } 4.8 \pm 0.4 \text { in the spironolactone } \\
\text { group and } 4.4 \pm 0.5 \mathrm{mEq} / \mathrm{l} \text { in the control group } \\
(P=0.2) \text {. }\end{array}$ \\
\hline
\end{tabular}


enzyme inhibitor or an angiotensin type 1 receptor antagonist were enrolled from 12 hospitals in the Tokai area in Japan. Seventy-eight PD patients received spironolactone at $25 \mathrm{mg} /$ day for 2 years, and 80 patients as the control group did not receive spironolactone. The rate of change in the LV mass index and LVEF in the spironolactone group improved significantly compared with the control group (LV mass index $-P=0.01, \mathrm{EF}-P=0.02$ ). In the present study, the effects of spironolactone were clearly shown in the males, whereas we could not show usefulness in the females because an insufficient number of females was enrolled. Serum potassium levels were significantly elevated in the spironolactone group at 6 months and 12 months after treatment with spironolactone. Only two patients in the spironolactone group developed hyperkalemia (maximum $\mathrm{K}$ level $6.0 \mathrm{mEq} / \mathrm{l}$ ); on the other hand, one patient in the control group developed hyperkalemia (K level $6.2 \mathrm{mEq} / \mathrm{l}$ ). There was no significant difference in the occurrence of hyperkalemia between the two groups $(P=0.62)$. Moreover, hypokalemia (potassium level< $3.0 \mathrm{mEq} / \mathrm{l}$ ) occurred in $25 \%$ of the control group and $15.4 \%$ of the spironolactone group [60].

\section{Protective effects on the peritoneal membrane in PD patients}

Peritoneal membrane deterioration associated with peritoneal fibrosis and neoangiogenesis is one of the important problems for patients receiving long-term PD [61]. Peritoneal injury is caused by bioincompatible peritoneal dialysis solution [62-64], peritonitis [65-67], and uremia $[68,69]$. MR antagonists have been reported to ameliorate peritoneal fibrosis in a rat peritonitis model [70, 71].

Two reports have discussed the effects of spironolactone on the peritoneal membrane in PD patients. Yelken et al. [72] reported $23 \mathrm{PD}$ patients who received spironolactone at $25 \mathrm{mg} /$ day for 6 months. After spironolactone administration, mean dialysate cancer antigen 125 significantly increased $(P=0.028)$, while the potassium level did not change significantly $(4.3 \pm 0.5$ at baseline vs $4.4 \pm 0.6 \mathrm{mEq} / \mathrm{l}$ after 6 months, $P=0.488)$. Vazquez-Rangel et al. [73] conducted a randomized, double-blinded, placebo-controlled study. Nine PD patients received spironolactone at $25 \mathrm{mg} /$ day for 6 months and underwent peritoneal biopsies when the PD catheter was placed and at the conclusion of follow-up. Spironolactone decreased the CD20 and collagen IV levels in the peritoneal biopsy specimens in the patients who received spironolactone compared with the placebo group. There was no significant difference in the potassium level between the 2 groups. The effects of MR antagonists on the peritoneal membrane in PD are still obscure. Future studies are necessary to determine whether MR blockade is useful for ameliorating peritoneal damage in PD patients.
These reports indicate that the risk of severe hyperkalemia is not significantly increased in patients receiving MR treatment, and the cardioprotective effects produced by MR antagonists are promising in PD patients.

\section{Conclusions}

Recent evidence has suggested that administration of low-dose MR antagonists does not significantly elevate the risk of hyperkalemia, and that cardioprotective effectiveness is provided by MR antagonists in both HD and PD patients. Moreover, MR antagonists are expected to improve mortality in ESRD dialysis patients. Since most of the studies have been small size and used short observation periods, further large-scale clinical studies are required to establish the protocol for use of MR antagonists in dialysis patients.

\begin{abstract}
Abbreviations
ACl: Aortic calcification index; CCV: Cardiovascular and cerebrovascular; CKD: Chronic kidney disease; EF: Ejection fraction; ESRD: End-stage renal disease; HD: Hemodialysis; ICAM1: Intracellular adhesion molecule 1; LV: Left ventricular; MAP: Mitogen-activated protein; MCP-1: Monocyte chemoattractant protein-1; MR: Mineralocorticoid receptor; NADPH oxidase: Nicotinamide adenine dinucleotide phosphate-oxidase; NF: Nuclear factor; NO: Nitric oxide; PD: Peritoneal dialysis; TNF-a: Tumor necrosis factor alpha
\end{abstract}

\section{Acknowledgments \\ Not applicable.}

Funding

There is no funding. The authors declare that no financial conflict of interest exists.

Availability of data and materials

Not applicable.

Authors' contributions

$\mathrm{YI}$ and MT planned the study, searched and collected the literatures, and wrote the manuscript. YS wrote the manuscript. FS and MM discussed the contents of manuscript with $\mathrm{YI}$ and MT. All authors read and approved the final manuscript.

\section{Competing interests}

The authors declare that they have no competing interests.

Consent for publication

Not applicable.

Ethics approval and consent to participate Not applicable.

Received: 1 September 2016 Accepted: 2 November 2016

Published online: 15 December 2016

References

1. Foley RN, Parfrey PS, Sarnak MJ. Epidemiology of cardiovascular disease in chronic renal disease. J Am Soc Nephrol. 1998;9 Suppl 12:16-23.

2. Masakane I, Nakai S, Ogata S, Kimata N, Hanafusa N, Hamano T, et al. An overview of regular dialysis treatment in japan (As of 31 December 2013). Ther Apher Dial. 2015;19:540-74.

3. Pitt B, Zannad F, Remme WJ, Cody R, Castaigne A, Perez A, et al. The effect of spironolactone on morbidity and mortality in patients with severe heart failure. Randomized Aldactone Evaluation Study Investigators. N Engl J Med. 1999;341:709-17. 
4. Zannad F, McMurray JJ, Krum H, van Veldhuisen DJ, Swedberg K, Shi H, et al. Eplerenone in patients with systolic heart failure and mild symptoms. N Engl J Med. 2011;364:11-21.

5. Pitt B, Remme W, Zannad F, Neaton J, Martinez F, Roniker B, et al. Eplerenone, a selective aldosterone blocker, in patients with left ventricular dysfunction after myocardial infarction. N Engl J Med. 2003;348:1309-21.

6. Pitt B, Reichek N, Willenbrock R, Zannad F, Phillips RA, Roniker B, et al. Effects of eplerenone, enalapril, and eplerenone/enalapril in patients with essential hypertension and left ventricular hypertrophy: the 4E-left ventricular hypertrophy study. Circulation. 2003;108:1831-8.

7. Greenblatt DJ, Koch-Weser J. Adverse reactions to spironolactone. A report from the Boston Collaborative Drug Surveillance Program. JAMA. 1973;225:40-3.

8. Kushner FG, Hand M, Smith Jr SC, King 3rd SB, Anderson JL, Antman EM et al. 2009 focused updates: ACC/AHA guidelines for the management of patients with ST-elevation myocardial infarction (updating the 2004 Guideline and 2007 focused update) and ACC/AHA/SCAI guidelines on percutaneous coronary intervention (updating the 2005 guideline and 2007 focused update): a report of the American College of Cardiology Foundation/American Heart Association Task Force on Practice Guidelines. Circulation. 2009;120:2271-306.

9. Lumb G, Newberne P, Rust JH, Wagner B. Effects in animals of chronic administration of spironolactone-a review. J Environ Pathol Toxicol. 1978;1:641-60.

10. Struthers AD. Aldosterone escape during angiotensin-converting enzyme inhibitor therapy in chronic heart failure. J Card Fail. 1996;2:47-54.

11. Barr CS, Lang CC, Hanson J, Arnott M, Kennedy N, Struthers AD. Effects of adding spironolactone to an angiotensin-converting enzyme inhibitor in chronic congestive heart failure secondary to coronary artery disease. Am J Cardiol. 1995;76:1259-65.

12. Ponda MP, Hostetter TH. Aldosterone antagonism in chronic kidney disease. Clin J Am Soc Nephrol. 2006;1:668-77.

13. Laragh $\mathrm{JH}$. Vasoconstriction-volume analysis for understanding and treating hypertension: the use of renin and aldosterone profiles. Am J Med. 1973;55:261-74.

14. Tanabe A, Naruse M, Naruse K, Hase M, Yoshimoto T, Tanaka M, et al. Left ventricular hypertrophy is more prominent in patients with primary aldosteronism than in patients with other types of secondary hypertension. Hypertens Res. 1997;20:85-90.

15. Coirini H, Magarinos AM, De Nicola AF, Rainbow TC, McEwen BS. Further studies of brain aldosterone binding sites employing new mineralocorticoid and glucocorticoid receptor markers in vitro. Brain Res. 1985;361:212-6.

16. Kornel L. Colocalization of 11 beta-hydroxysteroid dehydrogenase and mineralocorticoid receptors in cultured vascular smooth muscle cells. Am J Hypertens. 1994;7:100-3.

17. Bonvalet JP, Alfaidy N, Farman N, Lombes M. Aldosterone: intracellular receptors in human heart. Eur Heart J. 1995;16(Suppl N):92-7.

18. Robert V, Silvestre JS, Charlemagne D, Sabri A, Trouve P, Wassef M, et al. Biological determinants of aldosterone-induced cardiac fibrosis in rats. Hypertension. 1995;26:971-8.

19. Delcayre C, Swynghedauw B. Molecular mechanisms of myocardial remodeling. The role of aldosterone. J Mol Cell Cardiol. 2002;34:1577-84.

20. Duprez D, De Buyzere M, Rietzschel ER, Clement DL. Aldosterone and vascular damage. Curr Hypertens Rep. 2000;2:327-34.

21. Farquharson CA, Struthers AD. Spironolactone increases nitric oxide bioactivity, improves endothelial vasodilator dysfunction, and suppresses vascular angiotensin 1/angiotensin II conversion in patients with chronic heart failure. Circulation. 2000;101:594-7.

22. Sun Y, Zhang J, Lu L, Chen SS, Quinn MT, Weber KT. Aldosterone-induced inflammation in the rat heart : role of oxidative stress. Am J Pathol. 2002; 161:1773-81.

23. Rocha R, Martin-Berger CL, Yang P, Scherrer R, Delyani J, McMahon E, Selective aldosterone blockade prevents angiotensin II/salt-induced vascular inflammation in the rat heart. Endocrinology. 2002;143:4828-36.

24. Nagata K, Obata K, Xu J, Ichihara S, Noda A, Kimata H, et al. Mineralocorticoid receptor antagonism attenuates cardiac hypertrophy and failure in low-aldosterone hypertensive rats. Hypertension. 2006;47:656-64.

25. Struthers AD, MacDonald TM. Review of aldosterone- and angiotensin II-induced target organ damage and prevention. Cardiovasc Res. 2004; 61:663-70.

26. Fujita T. Aldosterone in salt-sensitive hypertension and metabolic syndrome. J Mol Med (Berl). 2008;86:729-34.
27. Brilla CG, Pick R, Tan LB, Janicki JS, Weber KT. Remodeling of the rat right and left ventricles in experimental hypertension. Circ Res. 1990;67:1355-64.

28. Lombes M, Oblin ME, Gasc JM, Baulieu EE, Farman N, Bonvalet JP. Immunohistochemical and biochemical evidence for a cardiovascular mineralocorticoid receptor. Circ Res. 1992;71:503-10.

29. Schiffrin EL. Effects of aldosterone on the vasculature. Hypertension. 2006; 47:312-8.

30. Van Belle E, Bauters C, Wernert N, Hamon M, McFadden EP, Racadot A, et al. Neointimal thickening after balloon denudation is enhanced by aldosterone and inhibited by spironolactone, and aldosterone antagonist. Cardiovasc Res. 1995;29:27-32.

31. Sawathiparnich P, Kumar S, Vaughan DE, Brown NJ. Spironolactone abolishes the relationship between aldosterone and plasminogen activator inhibitor-1 in humans. J Clin Endocrinol Metab. 2002;87:448-52.

32. Dinh QN, Young MJ, Evans MA, Drummond GR, Sobey CG, Chrissobolis S. Aldosterone-induced oxidative stress and inflammation in the brain are mediated by the endothelial cell mineralocorticoid receptor. Brain Res. 2016; 1637:146-53.

33. Leopold JA, Dam A, Maron BA, Scribner AW, Liao R, Handy DE, et al. Aldosterone impairs vascular reactivity by decreasing glucose-6-phosphate dehydrogenase activity. Nat Med. 2007;13:189-97.

34. Nagata D, Takahashi M, Sawai K, Tagami T, Usui T, Shimatsu A, et al. Molecular mechanism of the inhibitory effect of aldosterone on endothelial NO synthase activity. Hypertension. 2006;48:165-71.

35. Rajagopalan S, Duquaine D, King S, Pitt B, Patel P. Mineralocorticoid receptor antagonism in experimental atherosclerosis. Circulation. 2002;105:2212-6.

36. Takai S, Jin D, Muramatsu M, Kirimura K, Sakonjo H, Miyazaki M. Eplerenone inhibits atherosclerosis in nonhuman primates. Hypertension. 2005;46:1135-9.

37. Mueller KB, Bender SB, Hong $K$, Yang $Y$, Aronovitz $M$, Jaisser $F$, et al. Endothelial mineralocorticoid receptors differentially contribute to coronary and mesenteric vascular function without modulating blood pressure. Hypertension. 2015;66:988-97.

38. Min LJ, Mogi M, Li JM, Iwanami J, Iwai M, Horiuchi M. Aldosterone and angiotensin II synergistically induce mitogenic response in vascular smooth muscle cells. Circ Res. 2005;97:434-42.

39. Callera GE, Touyz RM, Tostes RC, Yogi A, He Y, Malkinson S, et al. Aldosterone activates vascular p38MAP kinase and NADPH oxidase via c-Src. Hypertension. 2005:45:773-9.

40. Tatsumoto N, Yamada S, Tokumoto M, Eriguchi M, Noguchi H, Torisu K, et al. Spironolactone ameliorates arterial medial calcification in uremic rats: the role of mineralocorticoid receptor signaling in vascular calcification. Am J Physiol Renal Physiol. 2015;309:F967-79.

41. Galmiche G, Pizard A, Gueret A, El Moghrabi S, Ouvrard-Pascaud A, Berger S, et al. Smooth muscle cell mineralocorticoid receptors are mandatory for aldosterone-salt to induce vascular stiffness. Hypertension. 2014;63:520-6.

42. Papadimitriou M, Vyzantiadis A, Milionis A, Memmos D, Metaxas P. The effect of spironolactone in hypertensive patients on regular haemodialysis and after renal allotransplantation. Life Support Syst. 1983;1:197-205.

43. Saudan P, Mach F, Perneger T, Schnetzler B, Stoermann C, Fumeaux Z, et al. Safety of low-dose spironolactone administration in chronic haemodialysis patients. Nephrol Dial Transplant. 2003;18:2359-63.

44. Hussain S, Dreyfus DE, Marcus RJ, Biederman RW, McGill RL. Is spironolactone safe for dialysis patients? Nephrol Dial Transplant. 2003;18:2364-8.

45. Gross E, Rothstein M, Dombek S, Juknis HI. Effect of spironolactone on blood pressure and the renin-angiotensin-aldosterone system in oligoanuric hemodialysis patients. Am J Kidney Dis. 2005;46:94-101.

46. Shavit L, Neykin D, Lifschitz M, Slotki I. Effect of eplerenone on blood pressure and the renin-angiotensin-aldosterone system in oligo-anuric chronic hemodialysis patients - a pilot study. Clin Nephrol. 2011;76:388-95.

47. Walsh M, Manns B, Garg AX, Bueti J, Rabbat C, Smyth A, et al. The safety of eplerenone in hemodialysis patients: a noninferiority randomized controlled trial. Clin J Am Soc Nephrol. 2015;10:1602-8.

48. Taheri S, Mortazavi M, Shahidi S, Pourmoghadas A, Garakyaraghi M, Seirafian $\mathrm{S}$, et al. Spironolactone in chronic hemodialysis patients improves cardiac function. Saudi J Kidney Dis Transpl. 2009;20:392-7.

49. McGill RL, Biederman RW, Getts RT, Hazlett SM, Sharma SB, Duran J, et al. Cardiac magnetic resonance imaging in hemodialysis patients. J Nephrol. 2009;22:367-72.

50. Flevari P, Kalogeropoulou S, Drakou A, Leftheriotis D, Panou F, Lekakis J, et al. Spironolactone improves endothelial and cardiac autonomic function in non heart failure hemodialysis patients. J Hypertens. 2013;31:1239-44. 
51. Feniman-De-Stefano GM, Zanati-Basan SG, De Stefano LM, Xavier PS, Castro AD, Caramori JC, et al. Spironolactone is secure and reduces left ventricular hypertrophy in hemodialysis patients. Ther Adv Cardiovasc Dis. 2015:9:158-67.

52. Matsumoto $Y$, Mori Y, Kageyama S, Arihara K, Sugiyama T, Ohmura H, et al. Spironolactone reduces cardiovascular and cerebrovascular morbidity and mortality in hemodialysis patients. J Am Coll Cardiol. 2014;63:528-36.

53. Matsumoto Y, Kageyama S, Yakushigawa T, Arihara K, Sugiyama T, Mori Y, et al. Long-term low-dose spironolactone therapy is safe in oligoanuric hemodialysis patients. Cardiology. 2009;114:32-8.

54. Lin C, Zhang Q, Zhang H, Lin A. Long-term effects of low-dose spironolactone on chronic dialysis patients: a randomized placebocontrolled study. J Clin Hypertens (Greenwich). 2016;18:121-8.

55. Nitta K, Akiba T, Nihei H. Aldosterone blockade and vascular calcification in hemodialysis patients. Am J Med. 2003;115:250.

56. Vukusich A, Kunstmann S, Varela C, Gainza D, Bravo S, Sepulveda D, et al. A randomized, double-blind, placebo-controlled trial of spironolactone on carotid intima-media thickness in nondiabetic hemodialysis patients. Clin J Am Soc Nephrol. 2010;5:1380-7.

57. Hausmann MJ, Liel-Cohen N. Aldactone therapy in a peritoneal dialysis patient with decreased left ventricular function. Nephrol Dial Transplant. 2002;17:2035-6

58. Taheri S, Mortazavi M, Pourmoghadas A, Seyrafian S, Alipour Z, Karimi S. A prospective double-blind randomized placebo-controlled clinical trial to evaluate the safety and efficacy of spironolactone in patients with advanced congestive heart failure on continuous ambulatory peritoneal dialysis. Saudi J Kidney Dis Transpl. 2012;23:507-12.

59. Yongsiri S, Thammakumpee J, Prongnamchai S, Tengpraettanakorn P, Chueansuwan R, Tangjaturonrasme S, et al. Randomized, double-blind, placebo-controlled trial of spironolactone for hypokalemia in continuous ambulatory peritoneal dialysis patients. Ther Apher Dial. 2015;19:81-6.

60. Ito $Y$, Mizuno M, Suzuki Y, Tamai H, Hiramatsu T, Ohashi H, et al. Long-term effects of spironolactone in peritoneal dialysis patients. J Am Soc Nephrol. 2014;25:1094-102.

61. Devuyst O, Margetts PJ, Topley N. The pathophysiology of the peritoneal membrane. J Am Soc Nephrol. 2010;21:1077-85.

62. Williams JD, Topley N, Craig KJ, Mackenzie RK, Pischetsrieder M, Lage C, et al. The Euro-Balance Trial: the effect of a new biocompatible peritoneal dialysis fluid (balance) on the peritoneal membrane. Kidney Int. 2004;66: 408-18.

63. De Vriese AS, Flyvbjerg A, Mortier S, Tilton RG, Lameire NH. Inhibition of the interaction of AGE-RAGE prevents hyperglycemia-induced fibrosis of the peritoneal membrane. J Am Soc Nephrol. 2003;14:2109-18.

64. Davies SJ. Longitudinal relationship between solute transport and ultrafiltration capacity in peritoneal dialysis patients. Kidney Int. 2004;66: 2437-45.

65. Selgas R, Fernandez-Reyes MJ, Bosque E, Bajo MA, Borrego F, Jimenez C, et al. Functional longevity of the human peritoneum: how long is continuous peritoneal dialysis possible? Results of a prospective medium long-term study. Am J Kidney Dis. 1994;23:64-73.

66. del Peso G, Fernandez-Reyes MJ, Hevia C, Bajo MA, Castro MJ, Cirugeda A, et al. Factors influencing peritoneal transport parameters during the first year on peritoneal dialysis: peritonitis is the main factor. Nephrol Dial Transplant. 2005;20:1201-6.

67. Davies SJ, Bryan J, Phillips L, Russell Gl. Longitudinal changes in peritoneal kinetics: the effects of peritoneal dialysis and peritonitis. Nephrol Dial Transplant. 1996;11:498-506.

68. Williams JD, Craig KJ, Topley N, Von Ruhland C, Fallon M, Newman GR, et al. Morphologic changes in the peritoneal membrane of patients with renal disease. J Am Soc Nephrol. 2002;13:470-9.

69. Sawai A, Ito $Y$, Mizuno M, Suzuki $Y$, Toda S, Ito I, et al. Peritoneal macrophage infiltration is correlated with baseline peritoneal solute transport rate in peritoneal dialysis patients. Nephrol Dial Transplant. 2011;26:2322-32.

70. Nishimura H, Ito Y, Mizuno M, Tanaka A, Morita Y, Maruyama S, et al. Mineralocorticoid receptor blockade ameliorates peritoneal fibrosis in new rat peritonitis model. Am J Physiol Renal Physiol. 2008;294:F1084-93.

71. Zhang L, Hao JB, Ren LS, Ding JL, Hao LR. The aldosterone receptor antagonist spironolactone prevents peritoneal inflammation and fibrosis. Lab Invest. 2014;94:839-50.
72. Yelken B, Gorgulu N, Gursu M, Yazici H, Caliskan Y, Telci A, et al. Effects of spironolactone on residual renal function and peritoneal function in peritoneal dialysis patients. Adv Perit Dial. 2014;30:5-10.

73. Vazquez-Rangel A, Soto V, Escalona M, Toledo RG, Castillo EA, Polanco Flores NA, et al. Spironolactone to prevent peritoneal fibrosis in peritoneal dialysis patients: a randomized controlled trial. Am J Kidney Dis. 2014;63:1072-4.

\section{Submit your next manuscript to BioMed Central and we will help you at every step:}

- We accept pre-submission inquiries

- Our selector tool helps you to find the most relevant journal

- We provide round the clock customer support

- Convenient online submission

- Thorough peer review

- Inclusion in PubMed and all major indexing services

- Maximum visibility for your research

Submit your manuscript at www.biomedcentral.com/submit

) Biomed Central 